\title{
Peanut aspiration leading to pneumorrhachis in a pre-schooler
}

\author{
Jhuma Sankar, Aditi Jain, C P Suresh
}

Department of Pediatrics, PGIMER, Dr RML Hospital, New Delhi, India

\section{Correspondence to} Dr Jhuma Sankar, jhumasankar@gmail.com
To cite: Sankar J, Jain A, Suresh CP. BMJ Case Reports Published online: [please include Day Month Year] doi:10.1136/bcr-2012007675

\section{DESCRIPTION}

Pneumothorax, pneumomediastinum (PM) and subcutaneous emphysema (SE) due to foreign body aspiration (FBA) are rarely reported in clinical practice. ${ }^{12}$ We present here a 3 -year-old boy who posed a diagnostic dilemma to us at presentation with SE following a subacute history of respiratory tract infection of 2 weeks duration. The child had been treated with oral antibiotics for 7 days prior to presentation, but the symptoms did not resolve and seemed to only worsen with time. Therefore, a possibility of FBA was strongly considered on the basis of his clinical picture and radiological investigations suggesting hyperinflation and collapse at different places with air leaks (figures 1 and 2). The CT scan of the chest also revealed epidural air extending from C5 to T12 vertebral level suggestive of external pneumorrhachis (figure 3). Accordingly, a diagnostic bronchoscopy was performed which revealed a peanut in the left main bronchus, which was successfully extracted leading to resolution of symptoms in the child. Although documented earlier, PM and SE secondary to FBA are very rare events. The association of FBA with pneumorrhachis is rarer still, with only one documented case of the same till date. ${ }^{3}$ We chose to report this case to highlight the diagnostic challenge the child had posed to us at presentation, which could only be confirmed due to a high index of suspicion. We also wish to highlight the rare association of pneumorrhachis with FBA as was seen in this child.

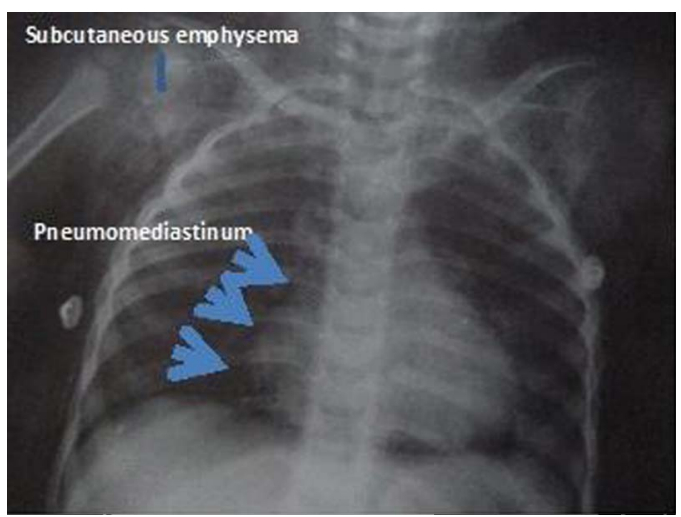

Figure 1 Chest $x$-ray of the child showing pneumomediastinum.

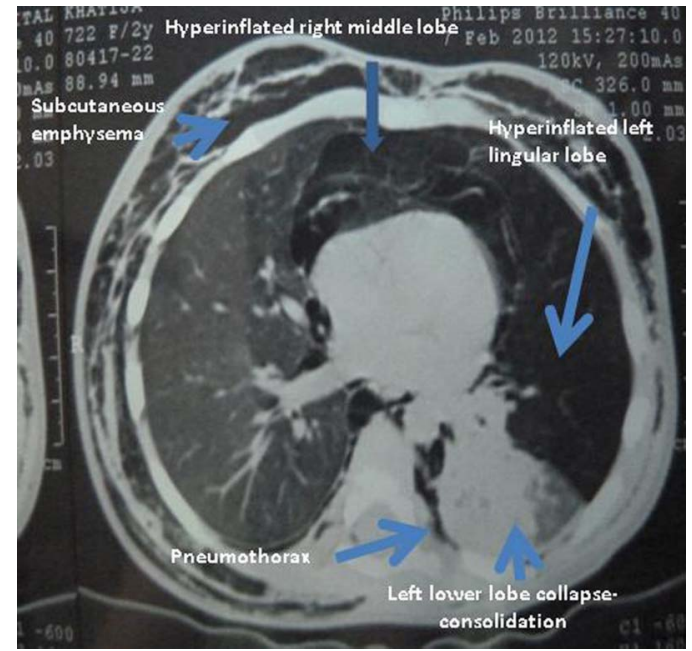

Figure 2 CT scan of the chest of the child showing hyperinflation and collapse of areas of the left lung.

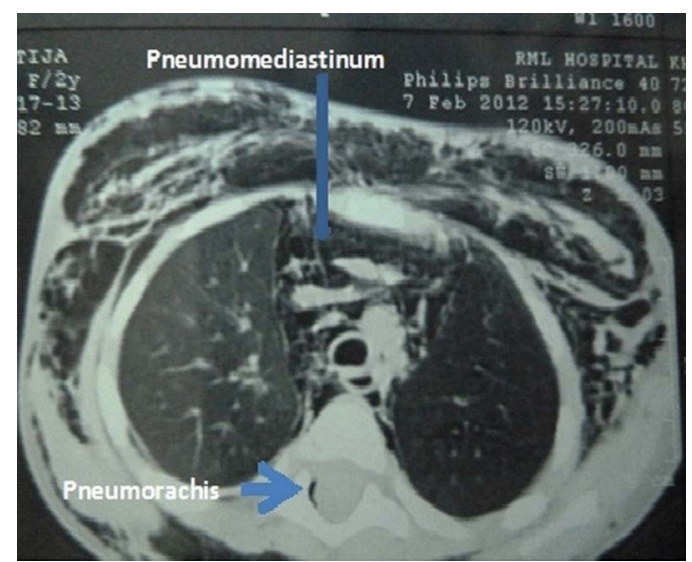

Figure 3 CT scan of the chest showing epidural emphysema or 'pneumorrhachis'.

\section{Learning points}

A possibility of foreign body aspiration should be considered in any child $<5$ years of age presenting with extra-alveolar air.

- Timely performed bronchoscopy may be lifesaving and lung saving in these children.

- Parents should be educated about the selection of food and toy materials in young children to avoid such unintentional injuries. 
Acknowledgements The authors would like to thank Dr NK Dubey and Dr Varinder Singh for their support in managing the case.

Competing interests None.

Patient consent Obtained.

Provenance and peer review Not commissioned; externally peer reviewed.

\section{REFERENCES}

1 Burton EM, Riggs W Jr, Kauffman RA, et al. Pneumomediastinum caused by foreign body aspiration in children. Pediatr Radiol 1989;20:45-7.

2 Tan HK, Brown K, McGill T, et al. Airway foreign bodies (FB): a 10-year review. Int J Pediatr Otorhinolaryngol 2000;56:91-9.

3 Otgün I, Fakioğlu E, Arda IS, et al. Subcutaneous emphysema and pneumomediastinum due to foreign body aspiration. Eur I Pediatr Surg 2008; 18:129-30

Copyright 2013 BMJ Publishing Group. All rights reserved. For permission to reuse any of this content visit http://group.bmj.com/group/rights-licensing/permissions.

BMJ Case Report Fellows may re-use this article for personal use and teaching without any further permission.

Become a Fellow of BMJ Case Reports today and you can:

- Submit as many cases as you like

- Enjoy fast sympathetic peer review and rapid publication of accepted articles

- Access all the published articles

- Re-use any of the published material for personal use and teaching without further permission

For information on Institutional Fellowships contact consortiasales@bmjgroup.com

Visit casereports.bmj.com for more articles like this and to become a Fellow 